\title{
The Problematic Nature of the Third Chapter of the Yoga Sütras and its Discussion of Powers
}

\author{
Carl Olson* \\ Allegheny College, USA
}

Submission: June 29, 2017; Published: September 15, 2017

*Corresponding author:: Carl Olson, Allegheny College, USA, Email: colson@allegheny.edu

\begin{abstract}
Because the Yoga Sūtras compiled by Patañjali devote one entire chapter to siddhas (powers) in a text of only four chapters this has caused scholars to offer various reasons for this problematic aspect of the text. After critically reviewing the opinions of scholars with respect to the imbalance in the text to understand Patañjali's decision, this essay places the text within the historical context of asceticism in India in order to grasp developments that might have shaped the compiler's mind. The historical development of asceticism in India was also accompanied by many narratives that stressed the importance of ascetic powers and helped to shape Patañjali's decision to make a quarter of his text about powers, even though these powers were acknowledged to be a hindrance to an aspirant's final goal.
\end{abstract}

Around the fourth century CE, the legendary Patañjali, compiler of the Yoga Sūtras, collected elements associated with ascetic practices in order to serve as a guide book for others. In his attempt to bring unity to the various pre-existing yogic traditions, Patañjali gathered together various elements into aphoristic, cryptic, and esoteric statements (sūtras) that lent itself more to remembrance and oral transmission. Because the text was incomprehensible, it invited commentaries by authorities with the intention of rendering the text comprehensible to the uninitiated. The Yoga Sütras consisted of four parts with about three quarters of the text focusing on technique and the third part of the text concerned with powers gained by yogis practicing the various disciplines. Hence a quarter of the text was concerned with these various supernatural powers called in the introduction to chapter three vibhūtis, but called siddhas in the remainder of the chapter.

According to the contents of the Yoga Sūtras and its third chapter, these powers include the ability to know, for example, the past and future, awareness of past rebirths, ability to read the mind of another person, awareness of the approach of one's death, intuiting the location of hidden objects, and intuiting the presence of the purușa (self). These are examples of cognitive (jñāna) powers. Powers (siddhas) that are more physical in nature include, for instance, the ability for a yogi to become invisible, have the strength of an elephant, ability to enter the body of another person, levitation, acute hearing, ability to fly, becoming disembodied, and gaining a perfected body. These various forms of mental and physical powers also find their way into Hindu, Buddhist, and Jain narratives that will be illustrated later in this essay.

A reader of the Yoga Sūtras is informed that these powers are a result of practicing the final three parts (samyama) of the path to liberation that begins with concentration (dhāranā) and includes meditation (dhyāna), and absorption (samādhi), and all major commentators agree that the various powers are results of practicing yoga, and are not the goal of the yogic path. In addition, practitioners are warned not to become attached to the powers gained by yogis because they are a trap that keeps a yogi attached to the world. Nonetheless, within the context of a "how to manual," it is curious that an entire quarter of the book is devoted to powers (siddhas). Patañjali obviously considered the acquisition of powers to be an essential aspect of the yogic path. This apparent oddity of the text has puzzled scholars, and various attempts have been made by scholars of yoga to attempt to make sense of this feature of the text. This essay proposes to reconsider and attempt to understand what might have motivated Patañjali to devote an entire chapter of his four chapter text to the subject of yogic powers. To meet this purpose of the essay, it is advisable to review interpretations of these powers by different scholars and then to place these powers into their historical context. Thirdly, examples of yogis/ascetics using powers in various narratives will be included because these stories are part of the cultural milieu in which Patañjali worked on the text. Because the yogi has been an ascetic figure traditionally in Indian culture, I have used the terms yogi and ascetic interchangeably.

\section{Scholarly Interpretations of Ascetic Powers}

In his magisterial, multi-volume work on the dharmaśāstra literature, P. V. Kane calls attention to the integral part that the siddhas (powers) play in the Yoga Sütras [1]. Kane asserts that his opinion is based on the fact that there are 35 references to

siddhas in the text out of a grand total of 195 sūtras. Kane goes on to discuss the origins of the various powers according to Patañjali. And he calls attention to a belief among tantrikas and yogis that mantras had the power to confer supernormal powers. 
An early discussion of the importance of ascetic powers in the West is offered by Charles Rockwell Lanman of Harvard University in 1917 for the American Philological Association. Lanman thinks that the practice of asceticism is motivated by the promise of its rewards. Lanman argues that some yogic powers are indubitably instances of hypnosis as in the case of entering another body and gaining power over the will of another person [2]. The role of hypnosis is questionable, although it is a reasonable position to take based on the subject matter that opens itself to speculation about its origins.

Max Weber [3], a preeminent and influential German sociologist, published The Religion of India in 1920 where he discusses the importance of Indian asceticism that he describes as "the most rationally developed in the world [3]." Weber traces its origins to the practice of "magical ecstasy" with the purpose of acquiring magical powers that extended to power over gods, who also practiced asceticism. Indian ascetics are characterized as "possessors of holy charisma and even revered as saints and wonder workers, giving them a power the Brahmans wished to monopolize for themselves [4]." The charisma (a Greek term referring to grace, favor, or gift) to which Weber points is characterized as a charisma of knowledge in the Indian cultural context. For readers of Weber's works, it is not surprising that he would discover something rational about asceticism because rationality plays a pivotal role in his sociological theory by operating on three different levels that include a pattern of individual action and belief, a cultural principle, and a characteristic of social organizations. With respect to individual action and belief, Weber distinguishes between non-rational and rational action. The former arises from deeply held feelings (affectual type) or long held customs (traditional type). The non-rational type of action is more common and is more akin to momentary reactions rather than carefully conceived plans. Compared to the non-rational; the rational response is a more deliberate, self-conscious, calculated response to ways of reaching one's goals, which is true of the yogi.

For Weber [3], a yogi's attainment of powers is a personal achievement that is not confined to any single group status. Weber thinks that the orgiastic-ecstatic features of Indian asceticism points to something irrational, and connects it to neuropathic states, a stance that anticipates the approach of cognitive science to some degree. According to Weber, charisma is a relational notion because it is based on perceptions of others that a particular person is endowed with extraordinary qualities, which renders it an ideal type and gives the charismatic authority to lead others, although such leadership is unpredictable and unstable. Taking what he terms an "other-worldly asceticism," Weber also writes about a "this-worldly asceticism," which he defines as an ordered, diligent, and temperate life that is suited to the development of an economic system such as capitalism. Dumont, a French sociologist, characterizes Weber's theory as "a miracle of empathy and sociological imagination [5]." In spite of Dumont's strong endorsement of Weber's theory, other thinkers would make their own contributions to the powers acquired by ascetics.
The earliest systematic scholarly study of the powers in Hinduism and Buddhism is Siddhi und Abhiññā: Einestudieüber die klassischen Wunder des Yoga written by Sigurd Lindquist [6] published in 1935. Comparing yogic siddhas with Buddhist rddhis, Lindquist conflates them with his psychological approach, and argues for their equivalence. He argues that powers are mental states brought about by a process of hypnosis, which results in a subjective creation of mental illusions and hallucinations [6]. Therefore, he reduces various types of powers to psychological phenomena. Over by warns against such a conflation of yogic and Buddhist powers because it is misleading, and creates a false impression about the traditional development of these powers. Thereby, Lindquist's approach misses instances of importation and appropriation of the powers [7].

Prior to Lindquist's study of the powers associated with the practice of yoga, JW Hauer [8] published Die Anfange der Yoga: Praxis imaltenIndien in 1922, and in 1958 he published Der Yoga: EinIndischer Wegzum Selbst. In the latter study, Hauer indicates that the powers are part physiological and part psychological [8]. Hauer is also interested with finding the origins of yoga, which he traces to a group of wandering ascetics called Vrātyas, who he identifies as Aryan, although not belonging to the orthodox Brāhmanicpriesthood [9]. The Vrātyas are a group that worshiped a primal god known by several names.

Working during the same time of Hauer's second book, Mircea Eliade's [10] Yoga: Immortality and Freedom, an influential work based on his doctoral research in India published in Paris in 1954 before its translation into English in 1958, reflects the scholar's approach to the study of religion and his theory of religion. Eliade likens the yogi, for instance, to a magician, the acquisition of powers as anostalgia for a divine condition, and "Yoga leads to a mythological perfection, the very perfection enjoyed by the personages of the Indian pantheon [10]." For someone who writes about initiation, it is not surprising that Eliade also finds an initiatory aspect to the practice of yoga and the attainment of powers. Eliade observes that the knowledge obtained by a yogi is akin to something both grandiose and paradoxical because it is equivalent to an appropriation: "For obtaining direct revelation of the purușa is at the same time to discover, to experience, an ontological modality inaccessible to the noninitiate [11]." As a phenomenologist, Eliade does not raise the question about the literal validity of the various powers by bracketing-out such a question because he wants to understand the powers on their own religious level and not impose his opinions and biases on the textual evidence.

Gaspar Koelman [12], a Jesuit scholar of yoga, is critical of Eliade's position, although he does agree about the magical quality of the powers. Koelman claims that it is not a yogi's acquisition of perfect knowledge about matter (prakrti) that forms a direct link to the powers, but it is rather "psychological and psychical pacification that matters [12]." Koelman views the acquisition of powers as an ascendancy of spirit over matter and not simply an extraordinary intuitive insight into the nature of reality that 
Eliade seems to suggest to him, resulting in a recovery of the self,its absolute awareness, and complete freedom.

Similar perspectives on yogic powers are offered by Corrado Pensa, Georg Feuerstein, and Gerhard Oberhammer. Viewing powers as intrinsic to the yogic path, Pensa thinks that they represent specializations connected with the path to liberation, but he also sees them as spurious aspects or magical residues without a textual foundation [13]. Feuerstein agrees with Pensa that powers do not fit into the text, refers to them as the magical aspect of the yogic path, asserts that they conflict with Patañjali's rationalism, and he wonders why this is the case [14].

According to Oberhammer, Patañjali's compiling of inherited elements of yoga into a consistent discipline represents the attempt to synthesize two forms of meditation: samādhi (concentration) and samāpattih (unification), which manifest different structures. In fact, unification is a method intended to appropriate a belief or truth without a real object because it only possesses representations and ideas [15]. In another work, he acknowledges the importance of yogic powers in the Yoga Sütras that he traces to a foundational stage of the development of the practice of yoga before it is superseded and humanized by Buddhism and Sāṃkhya [16,17].

In contrast to Feuerstein, Pensa, and Oberhammer, Jean Filliozat, a French scholar, argues that the various powers are "not miraculous in the sense of a suspension of the laws of nature, but they are deemed to be realizable through a higher and even integral knowledge of the laws of nature [18]." Filliozat offers a physiological explanation of some powers by the yogi who manipulates his/her external and internal body [19]. According to Filliozat, the yogi gains control by means of his/her practice of the muscular synergies of the body and/or the neuro-vegetative system.

Obeyeskere [20], a psychoanalytic anthropologist of South Asia, argues that yogic powers are reflections of a penetration into the depths of consciousness, and are connected to ego identity. By entering into meditative absorption, the ascetic comes into contact with deep recesses of the unconscious that are interrelated to an area where symbol creating occurs that forms the foundation for culture. What Obeyeskere calls hynomantic states include dream, trance, ecstasy, and concentration, which form models for myths that are logically ordered and coherent, representing ancient forms of knowing with a narrative structure. This implies that a narrative myth is modeled on a dream, yet removed from dream, but the images created in the dream are consonant with the prevailing cultural symbols and meaning [20]. Thus culture and dreams influence each other. Developing the implications of Obeyeskere's position, although he does not mention ascetic powers specifically, we can affirm that powers are a product of hynomantic states developed into narratives.

If the ecstatic person subordinates ordinary, delusional reality to a deeper reality that governs that person's existence, is such a person irrational? Obeyeskere [20] gives two reasons why the ecstatic's behavior is not irrational: "First, the ecstatic is acting in terms of the supramundane reality that he has constructed for himself; second, the average citizen does not see the behavior of the ecstatic as 'abnormal,' only different from his, but intelligible according to the central values of the culture that both share [21]." Moreover, the ecstatic continues to adhere to the pleasure principle because the new level of reality is meaningful and bearable. By taking into consideration extreme forms of asceticism, it is questionable whether or not the ascetic conforms to the pleasure principle as Obeyeskere claims because the ascetic represents a paradoxical exception to any pleasure principle.

Another scholarly viewpoint about the powers of ascetics is offered by Gerald Larson. After agreeing with previous scholars that Patañjali's assertion about the powers are obstacles to attainment of concentration, Larson acknowledges that the powers are part of the common experience for yogis. Larson cites two sūtras (YS 3. 37; 3. 51) that embody a skeptical cautionary attitude toward the powers, which he claims proves that the powers are not intended to be taken literally. He concludes that "These powers are most likely imaginative (kalpita) fantasies that arise in the process of doing yoga" [22]. He goes on to claim that the powers do not play any role as signs or marks of progress on the path.

Larson's evidence does not prove what he claims because the two textual references cited are both warnings and not skeptical expressions about whether or not the yogin actually gains and exercises such extraordinary powers. Moreover, Larson does not take the powers seriously. Why would Patañjali link samyama techniques with specific powers? This is a question that Larson does not answer. It is as if Larson cannot accept the possible reality of the various powers, and injects his personal skepticism into his interpretation, which is perfectly understandable for a person living in the twenty-first century that is far removed from the time period of the text compiled by Patañjali.

A different approach with respect to yogic powers is offered by Steven Phillips in his fine study of yoga philosophy. Since powers are an obstacle to concentration (samādhi), this is an excellent example of voluntarism, according to Phillips, because the "claim that siddhas follow upon thought and emotion coming under the control of the conscious being" [23]. What Phillips means by voluntarism is not simply a goal but also something that is an instrument, which means that concentration is part of the means to powers and not merely a final goal for the basic reason that it leads to something else. Therefore, the powers are a feature of the yogic path that cannot be renounced. From a critical perspective, Phillips argues that Patañjali's dualism of self and matter stands in opposition to his own yogic tradition of siddhas (powers), and the Indian philosopher does violence to the yogic tradition by setting aside the value of powers. Phillips offers the following judgment: "The ties between yoga practice and siddhas are in my judgment intrinsic, both culturally ... and in psychological fact. 
No one counts as a master yogin or yoginī who does not possess siddhas"[24]. Phillips thinks that the fundamental message of chapter 3 of the Yoga Sütras is that various powers flow from the practice of samyama.

Ian Whicher agrees with aspects of Phillips position especially the observation that powers are a natural by-product of the yogin's practice. As any worthwhile yogic instructor, Whicher warns that "Indulging in them only serves to inflate the ego and prevents spiritual growth precisely because the deployment of them presupposes that we invest our attention in the sensorial world or the desire for powers or control over it (reinforcing the subject-object duality, within prakrti that Yoga seeks to overcome) [25]." Whicher's observation is an echo of advice given by many yoga instructors and commentators over the centuries.

Finally, Sarbacker adopts the sociological theory of Pierre Bourdieu and its notion of habitus in order to interpret ascetic acquired powers, along with also contrasting the forces of doxa (worldview) and hexis (body culture) of a yogi. He thus states, "Psychic powers, in this interpretation, would represent the mastery of, or recovery of, the previously unconscious doxa and hexis, both of which in turn are reflected out into the world through communal experience [26]."

Sarbacker thinks that the community shares in the yogic powers of the ascetic, who strives to master his/her, inner psychic and somatic worlds and simultaneously one's relationship to the external world that theoretically gives power, control, and authority. In short, Sarbacker is saying that yogic techniques transform an ascetic internally, and this internal transformation affects the external world of the ascetic along with people who share his/her world. He explains further that "Whether literal or symbolic, actual or mimetic, the demonstration of yoga powers and the representation of such powers in literature encapsulate how the practice of yoga is a vehicle for the transfiguration of the human practitioner into a being of supernormal power and knowledge and a paradigm for a particular type of communal existence [27]." Sarbacker continues by sketching a series of interpretive possibilities.

Each of these learned opinions about the place of powers in the Yoga Sütras have some merit. But I think that there is an additional way to approach the subject within the Indian religious culture. In order to do this, it is important to briefly review the history of Indian asceticism to actually understand more fully and contextually the compiling of the in the fourth century CE. This historical approach contributes to a tendency to take Patañjali seriously when he affirms that he is merely a compiler of an ancient tradition or several traditions.

\section{A Brief Historical Sketch of Indian Asceticism}

A Rg Vedic hymn (10.129) called the Nāradīya Sūkta, a creation hymn, might have been influential on the development of asceticism, but it, at least, provided a context and inspiration for later developments in ascetic life [28]. The puzzling hymn begins by recounting a primordial darkness covering a watery chaos. Then, a life force arises by means of tapas (heat, a term that is also used later to refer to the practice of asceticism) and desire also arises, which forms the first seed of the mind. By means of wisdom, the kavi (seer) establishes the bond of existence within non-existence, suggesting a creation of the world through mind, a primeval consciousness considered divine. Forming an association between the existent within the non-existent, this connection is discovered by seers by means of inspired thinking. Other than this kind of inspired type of thinking, the text does not refer to meditation or contemplation practices.

For whatever reasons, the sacrificial cult of ancient Indian orthodox religion was considered too confining, rigid, and static for some seekers of religious experience. Some practitioners interiorized some Vedic sacrifices, which dispensed with the necessity of priestly expertise as evident in some texts of the Upanișads, such as the mentally performed horse sacrifice in the Brhadāranyaka (1.2.5-7) performed by a person; mention is also made of the mental sacrifice, the offering of bodily parts as oblations, and sacrifice of the breath in the Chändogya (5. 1923), and the Praśna (4.4) Upanișads where the mind becomes the sacrificer.

The majority of ascetic figures and movements existed outside of the dominant Vedic culture, although it is possible to find references to such groups as the long-haired Keśins and Vrātyas. In addition to their long hair, the Keśinswear dirty, discarded rags, wander naked or wear saffron colored robes that marks them as a renunciant group (RV 10.136.1-4). Reportedly, their alienation from the prevailing society placed them on the social margins much like the deity Rudra, who also resides on the margins of the social world in wild and dangerous places.

Sharing a conscious altering drug with Rudra, the Keśins could transform their condition into sensations of flight, able to read the mind of others, being able to transcend and view their bodies from a transcendent perspective, suggesting ecstatic experiences that are drug induced, although there is some scholarly debate about this point $[29,30]$. It is very likely that the Keśins, existing outside of the prevailing culture, represent precursors of later ascetic groups and share features with the early Buddhist, Jain, and other śramaṇa (renunicant) movements.

Another marginal social group is the Vrātyas (a term referring to those who have taken vows) identified as wandering warrior ascetics, who practiced self-flagellation and other forms of extreme asceticism, traveling by means of bullock carts. Apparently, Vedic priests attempted to induce them to join the orthodox culture via purification rites. Not previously married or fully adult, these ascetics engaged in raiding expeditions for cattle, fighting, and small scale warfare in order to release their aggressive tendencies [31]. In addition to their martial exploits, they also perform Vedic rites in the forest for their community [32]. Retaining their leadership positions, some Vrātyas remained unmarried, while others played a role expanding the reaches of 
Vedic culture. They are described in the Atharva Veda (15) as dressed in black with two ram skins over their shoulders and wearing a turban. Their marginal status to Vedic culture is evident in a ritual called the "great vow" (mahāvrata), a rite characterized by obscene dialogue and sexual intercourse with a prostitute by a leader that is preceded by breath control exercises [33].

In addition to these obscure groups mentioned in Vedic literature, there are also other ascetic groups referred to by the generic term śramana (renunciant) that are groups that include Jains, Buddhists, and Ājīvikas, originating historically around the fourth-fifth centuriesBCE. Calling attention to the martial imagery in Jain texts, Dundas draws a link between the śramana groups and the Vrātyas, who he thinks may have served as ascetic models [34]. This is disputed by Samuel because the Buddhist and Jain teachings are not martial in spirit and thus not a major predecessor for these movements, even if one grants the influence of some imagery and organizational structure [35].

During the historical period when Buddhists, Jains, and Ajjīvikas ascetic movements were developing, Indian culture was experiencing several important changes that increased the chances of individuals adopting an ascetic lifestyle. Probably, the rise of urban life was a central motivating factor because it provided people with more liberty of behavior and thought that contributed to an atmosphere of changing values. The hot, humid climate and closer living arrangements fostered by urban life enhanced the spread of contagious diseases and death. Urban expansion and agricultural innovations were accompanied by population growth.

Economic changes increased job specialization and mercantile activity, which made increased travel necessary between the growing urban centers with their expanding populations. Buddhists and Jains found strong economic support from merchants, bankers, and kings. Political changes placed more power into fewer hands. The political, social, and economic flux caused uncertainty, gave rise to questioning the prevailing social hierarchy, reconsideration of the meaning of life, and contributed to alternative choices about lifestyle.

The types of historical changes affecting early Buddhism and Jainism can also be inferred from ancient Vedic and Upanișadic texts that testify to the existence of a religious skepticism, an anti-priestly bias, acknowledgment of the existence of ascetic groups, and an advocacy of ascetic practice in the form of yogic discipline. Within some Rg Vedic passages, doubts are raised about the existence of the gods based on the claim that no one has seen a particular deity (RV 8.89), and another passage indicates that people have doubts about the existence of gods (RV 2.12). These types of examples from the Vedic literature are indicative of the quest for absolute certainty and the absolute that forms a bridge to the Upanișadic literature and its secret teachings about the relationship between the self and Brahman (identified as the ultimate reality).
The Upanișadic texts overcome the priestly dominance by interiorizing some Vedic sacrifices and transforming them into mental operations performed by the individual without the services of priestly expertise as previously noted. The śramanas (ascetic groups) appear in the Bṛhadāranyaka Upanișad (4.3.22) in a negative association with thieves, abortionists, and two pariah groups (Chandalas and Pulkasas). A six fold path of yogi is prescribed by the Maitri Upanișad (6.18) that includes breath control, withdrawal of the senses, meditation, concentration, contemplation, and finally absorption, while a briefer version appears in the Mundaka Upanisad (1.2.11) that includes practicing the following two aspects: tapas (austerity) and śraddha (faith) in the forest.

It is difficult to know what the text means precisely with respect to these two practices especially the role of faith. What is remarkable is the close resemblance of the path of the Maitri Upanișad to the classical yogic path contained in Patañjali's compilation of the Yoga Sütras. Not all Vedic texts are, however, advocates of an ascetic life-style because the Aitareya Brāhmaña (7.13-18) calls into question, for example, ascetic attire and the conflicting attitudes of householders towards ascetics that run the range of reverence to distrust [36]. And there evolves the widespread figure of the false ascetic, who is depicted as greedy, sexually dangerous, dishonest, and immoral [37].

It is precisely the acquisition of power that functions as a motivating factor for someone choosing an ascetic lifestyle in traditional India along with attempts to eradicate the effects of transgressions and ritual failures, and to secure a place in the afterlife [38]. And the later Upanișads suggest a search for an absolute entity as a motive because it was deemed necessary to go beyond the practice of tapas, which began to be understood to have limitations with respect to achieving a higher goal that embodied gaining control of and maintaining the universe [39,40]. Moreover, it was this historical tradition that shaped a thinker like Patañjali. And an aspect of literary history-verbal or oral-that also shaped Patañjali was the plethora of narratives about ascetics exercising powers gained through their regimen.

\section{Narratives about Power}

Besides the development of various ascetic/yogic types of movements that were often motivated by individuals seeking powers, the major epic texts-Mahābhārata and Rāmayāna-of Indian literature contain many narratives about the display and use of ascetic powers. According to the Mahābhärata (12.115119), once there was an ascetic of such goodness that flesh-eating wild animals were akin to his disciples in the forest.

A dog, weak and emaciated from eating only fruits and roots, like the ascetic, became attached to him out of affection, developed a tranquil demeanor, and heart similar to that of a human being. One day, a hungry leopard came to where they were residing and was about to seize the dog as its prey when the dog begged the ascetic to save him. The sage turned him into a leopard, and then, 
when a tiger attacked, into a tiger, and then a rutting elephant, and a lion. Now that he was carnivorous, all the other animals feared him and stayed away, and finally he wanted to eat the ascetic, who read his thoughts and turned him back into a dog, which was his proper form by birth. The dog moped about unhappily until the ascetic drove him out of the heritage. This narrative captures the ascetic's power to turn another creature into any form. Other parts of the great epic highlight other ascetic powers such as an ascetic's possession of a divine eye that allows him to see into the future (Mbh 1.111.18-19), the ability to fly (Mbh 3.156.15), power to suddenly disappear (Mbh 3.289.24), or manifests control over nature (Mbh 3,109.6-9).

Similar types of ascetic powers can be found in the Rāmayāna with narratives about an ascetic who possesses power over human biology by being able to create a son for a woman by means of his mind (Rām 1.29.11-18). By means of his powers, another ascetic creates a beautiful pondcalled the pond of the five Apsarases (Rām3.9.11-12). The monkey Hanumān, a devoted servant of the hero Rāma, and his army get lost in a cavern where they encounter a female ascetic, and he asks her for help getting out of the cavern in order to accomplish their task of rescuing Sītā, wife of the heroic Rāma. The female ascetic agrees to use her power to help the floundering monkeys, and instructs them to close their eyes, which frees them instantaneously (Rām 4.52.1-10).

According to the Sāmaññaphalasutta of the Digha Nikāya, the historical Buddha could become one or many, could become visible or invisible, pass through a wall, move through solid ground, remember previous births, walk on water, or travel crosslegged through the sky. The Samyutta Nikāya (2.212; 5.264-65) states that the Buddha can become one of many, suddenly vanish, pass bodily through a wall or mountain, travel like a bird, or touch the moon and sun. His mental powers (telepathy, clairaudience, and clairvoyance) and his wisdom surpass that of even the gods.

Even though these powers were evident of his advanced spiritual status, the Buddha is depicted rebuking a man who displays similar types of powers in the Cullavagga (5.7). According to this account, Piṇ̣olaBhāradvāja, a disciple of the Buddha, rises into the air, takes a bowl from the top of a pole, and flies three times around the city. The Buddha did not favor such displays because it gave ordinary people the wrong impression about the importance of powers and could potentially distract a practitioner from the path to liberation.

Mahāvīra is no less powerful than the Buddha, according to Jain literature. The Ākārānga Sūtra (2.15.260) and the Kalpa Sūtra (121) offer similar accounts of the powers gained by Mahāvira when he attains liberation by mentioning omniscience, knowledge of the condition of all worlds, remember former births, and ability to read other minds. What stands out about this list is the emphasis on mental powers over physical prowess. According to the Uttaradhyayana Sütra (30.7-37), these powers are the by-product of six types of internal and six kinds of external austerities. The external austerities are fasting, five kinds of abstinence, collecting alms, abstention from rich food, mortification of the flesh, whereas the internal forms of practice include expiation of sins, politeness, serving the teacher, study, meditation, and abandoning the body.

Internal forms of asceticism focus on human attitudes, thoughts, and emotions, which cannot be perceived by others, whereas external forms are related to the interaction between ascetics and others, restricting association with worldly objects, and exposing ascetic practices to the gaze of others [41-43]. Any display of these powers is intended to glorify Jain teachings and to assist the flourishing of the religion.

Other bodies of literature relate narratives that highlight the powers of ascetic/yogic figures. A good example of additional literature is Purānas. Before these narratives were composed, they circulated orally within the culture as did the two epics. It does not take much of a leap of imagination to conclude that the historical development of various types of ascetic groups and individuals and the widespread oral and written body of narratives about the existence of powers shaped the mind of Patañjali when he compiled the Yoga Sütras. Because ascetic powers were closely associated with ascetics and tales about them were prevalent, Patañjali would have been negligent if he had not considered them in his text. From one perspective, Patañjali acknowledges that these powers do arise, are genuine, and not something created by the yogi's imagination. This is an insider's perspective and stands in sharp contrast to the scholars standing outside of the yogic tradition discussed earlier in this essay. From another perspective, Patañjali asserts that these powers are a hindrance to further spiritual advancement and the achievement of an aspirant's ultimate goal, which is release from the cycle of life.

\section{Concluding Remarks}

The narratives about ascetic powers from Buddhist, Jain, and Hindu texts are evidence of the popular folklore and convictions surrounding the life and exploits of ascetics/yogis. Thus, as asceticism in its many manifestations developed in ancient India, its historical evolution is accompanied by narratives depicting extraordinary powers. It is this plethora of narratives both oral and written-about ascetic powers that shape the attitude of Patañjali about the nature of yoga in the fourth century CE as he attempts to compile and systematize its techniques.

Since the association between powers and ascetic life is so pervasive in the culture, it is this pervasiveness and popular, unquestioning assumptions about asceticism to which Patañjali needed to respond. Acting as a compiler of the Yoga Sütras, if we accept the traditional understanding of his role, Patañjali needed to make sense of a religious phenomenon-extraordinary yogic powers-in order to do justice to an aspect of asceticism that was unquestionably accepted by many Indians. Therefore, Patañjali included an entire section of the text devoted to a discussion and treatment of powers (siddhas) in order to treat his subject in a through manner, which suggests that various kinds of powers are an essential aspect of the ascetic/yogic life style. Moreover, 
the cultural context in which Patañjali lives, compiles, and writes calls for him to devote some of his text to making sense of ascetic powers. If Patañjali did not consider ascetic powers, he would have been negligent in his vocation. Instead, he takes the folk narratives and oral traditions seriously by devoting an entire chapter to a discussion of ascetic powers in a four chapter book, even though some scholars are perplexed by this alleged over emphasis on powers.

\section{References}

1. Kane PV (1973) History of Dharmaśästra. Bhandarkar Research Institute 5(2): 1452.

2. Charles Rockwell L (1917) Hindu ascetics and their powers, transactions and proceedings of the American Philological Association 48: 147 .

3. Weber M (1958) The religion of india: the sociology of hinduism and buddhism, trans. In: Hans H Gerth, Don Martindale (Eds.), The Free Press, USA, pp. 148-149.

4. Ibid p. 155.

5. Dumont L, Hierarchicus H. An essay on the caste system, trans. Mark Sainsburg Chicago: University of Chicago Press, USA, p. 30.

6. Lindquist S (1935) Siddha and Abhiñ̃nā: EineStudieüber die klassichen Wunder des Yoga Uppsala University, Europe, p. 70.

7. Richard R (2012) Overby on the appearance of siddhis in chinese buddhist texts, in yoga powers: extraordinary capacities attained through meditation and concentration, Knut A Jacobsen (Leiden, Boston: Brill), USA, pp. 131-141.

8. Hauer JW (1958) Der Yoga: EinIndischerwegzum Selbst (Stuttgart: W Kohlhammer), Germany, p. 319.

9. Ibid, p. 91.

10. Eliade M (1969) Yoga: immortality and freedom, trans. In: Willard R. Trask (Ed.), Princeton: Princeton University Press, USA, p. 90.

11. Ibid, p. 94.

12. Koelman GM (1970) Pātañjala Yoga: from related ego to absolute self. Papal Athenaeum. India, p. 244.

13. Pensa C (1969) On the purification concept in indian tradition, with Special Regard to Yoga East and West 19: 194-228.

14. Feuerstein G (1980) The philosophy of classical yoga, St. Martin's Press, New York, p. 140.

15. Oberhammer G (1965) Meditation and Mystik des Patañjali. In: Frauwallner E, Oberhammer G (Eds.), Weiner Zeitschriftfür die Kunde Sud-und Ostasiens und ArchivfürIndische Philosophie. Leiden: E. J. Brill, Netherlands, pp. 113-114.

16. Oberhammer G (1977) Strukturenyogischer Meditation: UntersuchungenzurSpiritualität des Yoga (Wien: Austrian Academy of Sciences, Austria, p. 223.

17. Malinar A (2012) is critical of Oberhammer's position because textual evidence is indicative of something else. She writes, It seems that the powers of yogin have become an integral part of many yoga traditions, not in spite of Sāṃhya philosophy, but because of it in Yoga Powers in the Mahābhārta. In: Jacobsen KA (Ed.), Yoga Powers: Extraordinary Capacities Attained Through Meditation and Concentration. Leiden, Boston: Brill, Netherlands, p. 58.

18. Filliozat J (1991) Religion philosophy yoga, trans. Maurice Shukla. MotilalBanarsidass Publishers, India, p. 348.
19. Ibid, pp. 350-358.

20. Obeyesekere G (1981) Medusa's Hair: an essay on personal symbols and religious experience. University of Chicago Press, USA, pp. 180181.

21. Obeyesekere G (1990) The work of culture: symbolic transformation in psychoanalysis and anthropology. University of Chicago Press, USA, p. 380.

22. Larson GJ (1987) Introduction to the philosophy of sāmkhya. In: Larson GJ, Bhattacharya RS (Eds.), Sāṃkhya A Dualist tradition in indian philosophy, encyclopedia of indian philosophies IV. Princeton: Princeton University Press, USA, p. 130.

23. Phillips $S$ (2009) Yoga, karma, and rebirth: a brief history and philosophy. Columbia University Press, USA, p. 141.

24. Ibid, p. 60

25. Whicher I (1998) The integrity of the yoga darśana: a reconsideration of classical yoga. State University of New York Press, USA, p. 215.

26. Sarbacker SR (2012) Power and meaning in the yoga sūtra of patañjali. In: Jacobsen KA (Ed.), Yoga Powers: extraordinary capacities attained through meditation and concentration. Leiden, Boston: Brill, USA, p. 124.

27. Ibid (2015) For a discussion of ascetic powers and related themes, see Carl Olson, Indian Asceticism Power, Violence, and Play. Oxford University Press, USA, p. 218.

28. (2010) For a comparison of the lifestyle of ancient Christian desert ascetics and Hindu figures, see Oliver Freiberger, Locating the Ascetic's Habitat: Toward a Micro-Comparison of Religious Discourses, History of Religions 59/2: 162-192.(2009) Der Askesediskurs in der Religionsgeschichte: Einevergleichende Untersuchung brahmanischer and frühchristlicher, Texte Studies in Oriental Religions 57 Wiesbaden: Harrassowitz, Germany.

29. Werner K (1977) Yoga and the Rg Veda: an interpretation of the kesin hymn. Religious Studies 13(3): 289-302.

30. Heesterman JC (1993) The broken world of sacrifice: essays in ancient indian ritual. University of Chicago Press, USA, p. 306.

31. Witzel M (1995) Early sanskritization. Electronic Journal of Vedic Studies 1(4): 18.

32. White DG (1991) Myths of the dog-man. Chicago and London: University of Chicago Press, USA, p. 95.

33. Flood G (1996) An Introduction to Hinduism. Cambridge University Press, USA, p. 79.

34. Dundas P (1991) The digambara jain warrior. In: Carrithers $M$, Humphrey C (Eds.), The assembly of listeners: Jains in Society, Cambridge University Press, USA, pp. 173-174.

35. Samuel G (2008) The origins of yoga and tantra: indian religions to the thirteenth Century. Cambridge University Press, USA, p. 128.

36. Olivelle P (2006) emphasizes the ways that asceticism is deeply embedded in culture when he identifies three levels of asceticism: (1) root asceticism that represents a basic asceticism characterized by self-restraint and is manifested in restriction on personal desires; (2) cultural asceticism representing specific tools for members to exercise self-control; (3) elite asceticism refers to extraordinary forms of selfcontrol that only a small minority is able to practice with the purpose of achieving specific goals in the Ascetic and the Domestic in Brahmanical Religiosity. In: Freiberger 0 (Ed.), Asceticism and Its Critics: Historical Accounts and Comparative Perspectives, Oxford: Oxford University Press, USA, pp. 25-42.

37. Madan TN (1987) Non-Renunciation: themes and interpretations of hindu culture. Oxford University Press, India. 
38. O'Flaherty WD (1973) Asceticism and eroticism in the mythology of śiva. Oxford University Press, Londan, pp. 44-68.

39. Basham AL (1989) The origins and development of classical hinduism. In: Zysk KG (Ed.), Beacon Press, USA, p. 51.

40. JAB V (1957) Buitenen, Dharma and Moksha, Philosophy East and West VII/1(2): 33-34.

This work is licensed under Creative Commons Attribution 4.0 License

DOI:10.19080/JYP.2017.03.555601
41. Cort JE (2001) Jains in the world: religious values and ideology in india. Oxford, New York: Oxford University Press, USA, pp. 120-121.

42. Von Glasenapp H (1999) Jainism: an indian religion of salvation. Motilal Banarsidass Publishers, India, pp. 235-236.

43. Williams R (1963) Jaina yoga. Oxford University Press, USA, pp. 238239.

\section{Your next submission with Juniper Publishers will reach you the below assets}

- Quality Editorial service

- Swift Peer Review

- Reprints availability

- E-prints Service

- Manuscript Podcast for convenient understanding

- Global attainment for your research

- Manuscript accessibility in different formats ( Pdf, E-pub, Full Text, Audio)

- Unceasing customer service

Track the below URL for one-step submission https://juniperpublishers.com/online-submission.php 